Article

\title{
Future Seasonal Drought Conditions over the CORDEX-MENA/Arab Domain
}

\author{
Marlene A. Tomaszkiewicz
}

check for updates

Citation: Tomaszkiewicz, M.A. Future Seasonal Drought Conditions over the CORDEX-MENA/Arab Domain. Atmosphere 2021, 12, 856 https://doi.org/10.3390/atmos 12070856

Academic Editors: Corrado Camera and Georgios Zittis

Received: 6 May 2021

Accepted: 27 May 2021

Published: 30 June 2021

Publisher's Note: MDPI stays neutral with regard to jurisdictional claims in published maps and institutional affiliations.

Copyright: (C) 2021 by the author. Licensee MDPI, Basel, Switzerland. This article is an open access article distributed under the terms and conditions of the Creative Commons Attribution (CC BY) license (https:/ / creativecommons.org/licenses/by/ $4.0 /)$.
United Nations Economic and Social Commission for Western Asia, Beirut 1107 2260, Lebanon; tomaszkiewiczm@un.org

\begin{abstract}
Seasonal drought is often overlooked because its impacts are less devasting than meteorological or hydrological drought. Nevertheless, short-term drought can have significant impacts on soil moisture content, agricultural crop yield, and sand and dust storms. Using data obtained from bias-corrected regional climate modelling ( $R C M)$ outputs, future seasonal drought is investigated over the water-scarce Arab domain using SPI-3. The climate modelling outputs include three downscaled mainframe GCMs downscaled using a single RCM for two climate scenarios: RCP4.5 and RCP8.5. Results across the region exhibit spatial and temporal variability. For example, Rift Valley, in the eastern sub-Sahara, projects less frequent and less severe drought, particularly during the winter (DJF) months. Conversely, the Morocco Highlands and adjacent Mediterranean coast signals a dramatic increase in drought by end-century during winter (DJF) and spring (MAM). Moderate increase in drought indicated in the greater Mashreq in spring (MAM) can be linked to sand and dust storm risk. Thirdly, autumn drought (SON) is linked to increased forest fire risk in the Levant. Projected increases in drought frequency and severity call for adaptation measures to reduce impacts.
\end{abstract}

Keywords: drought; climate change; Arab domain

\section{Introduction}

The Middle East and North Africa, also known as the Arab region, is perpetually faced with multiple complex issues that arguably possess one common denominator: drought. Water scarcity is most obviously connected to drought, impacting agriculture and food security [1-4], ecosystems [5,6], drinking water demand [7], and energy sustainability [1]. Drought also perpetuates other climate-related extreme events such as floods [8], forest fires [9], desertification [6], and sand and dust storms [10-12]. Lastly, geopolitical challenges in the region have been interlinked to drought including migration $[13,14]$, conflict [1,14-16], and vulnerable population groups $[1,4,17]$.

Drought is not a new phenomenon in the region. Geological evidence has revealed drought recurrence as early as the Aceramic Neolithic period [18,19]. Several atmospheric circulation patterns influence precipitation patterns, most notably North Atlantic Oscillation (NAO) and El Niño-Southern Oscillation (ENSO), which have partially triggered the most extreme disasters in the region $[17,20,21]$. Drought was blamed for devasting famine in Sudan during the 1980s and 1990s [4], the near collapse of the camel husbandry economy in Jordan during the mid-20th century [22], and a severe decline wheat and barley production during 2007-2010 in the Tigris-Euphrates Basin [14]. Thus, the question is not whether drought is a recurring problem. Rather, it is whether drought frequency and severity are increasing due to climate change and the potential impacts upon differing sectors.

Often overlooked due to smaller scale, short-term or seasonal drought can be crucial to detect reduction in soil moisture content and is a risk factor for climate-related extreme events. Over the last 75 years, a study conducted by Spinoni et al. [23] detected over 420 short term drought events in countries across the Arab region. Although these events are less severe and shorter in duration compared to meteorological drought, they occur over twice as often [23].Trend analysis in the region has revealed an expected increase in 
droughts, particularly in the Maghreb, Sahel, Levant, and Arabian Peninsula [21,24-26]. Although precipitation exhibits interannual variability, meteorological data reveals generally decreasing rainfall over the last half-century in Marrakesh (Morocco), Tripoli (Libya), Latakia (Syria), Sana'a (Yemen) [26], Jeddah (Saudi Arabia) [27], and Baghdad (Iraq) [12,26]. However, trend analysis is not sufficient, partly due to sparsely located meteorological stations. Moreover, trend analysis may not reveal short-term drought linked to crop failure, sand and dust storms, and other impacts. Climate modelling outputs are best to assess future conditions. This study uses bias-corrected regional climate modelling outputs coupled with a widely known drought index (SPI) to predict short-term drought impacts in the region. Previous drought index analyses in the region have been limited to selected areas, focused on longer meteorological drought, and have not considered climate change impacts (i.e., $[16,22,23,27-30])$.

\section{Data and Analysis Methods}

\subsection{MENA-CORDEX and RICCAR}

Regional climate modelling (RCM) outputs used for this study were obtained from the Middle East/North Africa (MENA) Domain, established as part of the Coordinated Regional Climate Downscaling Experiment (CORDEX) and bias-corrected for the Regional Initiative for the Assessment of Climate Change Impacts on Water Resources and SocioEconomic Vulnerability in the Arab Region (RICCAR). Also known as the Arab Domain (Figure 1), the resultant CORDEX boundaries establish common RCM outputs across all Arab States (Algeria, Bahrain, Djibouti, Egypt, Iraq, Jordan, Kuwait, Lebanon, Libya, Mauritania, Morocco, Oman, State of Palestine, Qatar, Saudi Arabia, Somalia, Sudan, Syria, Tunisia, United Arab Emirates (UAE), and Yemen) (excluding Comoros due to its distant geographical location) and includes transboundary water basins and atmospheric processes affecting the region [21].

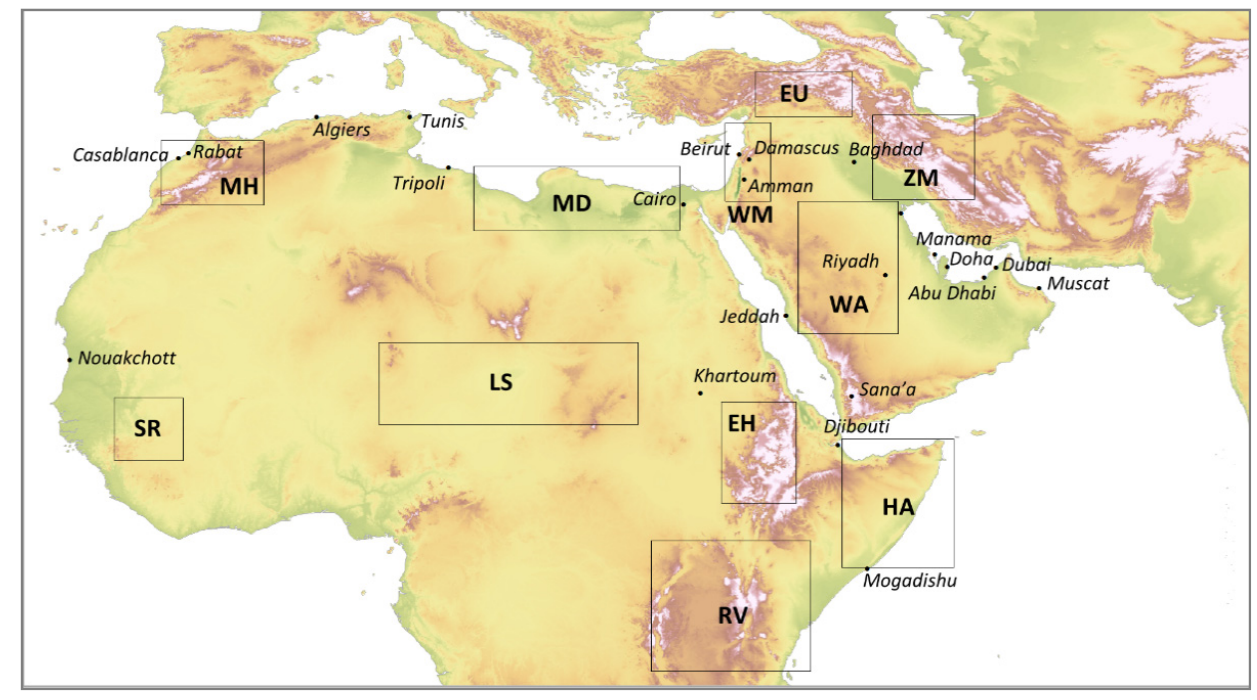

Figure 1. The CORDEX-MENA/Arab Domain and selected subdomains: Senegal River (SR), Moroccan Highlands (MH), Mediterranean Coast (MD), Lower Sahara (LS), Ethiopian Highlands (EH), Rift Valley (RV), Horn of Africa (HA), Western Mashreq (WM), Upper Euphrates Basin (EU), Zagros Mountains (ZM), and Western Arabian Peninsula (WA).

Three global climate models (GCMs) were downscaled based on a $0.44^{\circ}$ grid $(\sim 50 \mathrm{~km})$ using one RCM (Table 1). Two climate scenarios evaluated as part of CMIP5 were selected: RCP4.5, representing a moderate scenario and RCP8.5 representing an extreme, or business-as-usual scenario. Subsequently, bias-correction was conducted using the Distribution Based Scaling method [31] coupled with the WATCH-forced ERA-Interim 
(WFDEI) dataset [32] for the period 1980-2009 [21,33]. Although bias-correction can invite controversy, the methodology is recommended for hydro-climate analyses [34-36].

Table 1. Global climate models and the regional climate model used for the downscaling over the CORDEX-MENA/Arab Domain.

\begin{tabular}{cccc}
\hline Model Type & Name & Institute & Reference(s) \\
\hline GCM & CNRM-CM5 & CNRM (Centre National de Recherches Météorologiques, & [37] \\
GCM & EC-EARTH & Paris, France) & [38] \\
GCM & GFDL-ESM2M & GFDL (Geophysical Fluid Dynamics Laboratory, & [39] \\
RCM & RCA4 & Princeton, NJ, United States) & SMHI (Swedish Meteorological and Hydrological Institute, \\
& & Norrkoping, Sweden) & [40] \\
\hline
\end{tabular}

Projected changes in seasonal temperature, previously unpublished, indicate an increasing trend across the Arab domain. In general, changes in temperature are generally distributed throughout the year for both RCP4.5 (Table 2, Figure S1) and RCP8.5 (Table 3, Figure S2). However, the region generally projects an increase $>1.5^{\circ} \mathrm{C}$ by mid-century, compared to the recent reference period. In addition, certain subdomains signal a greater warming trend during winter (DJF). For example, the Upper Euphrates projects an increase of $2.9-3.5^{\circ} \mathrm{C}$ by mid-century. Also, the temperature is expected to increase $3.0-3.7^{\circ} \mathrm{C}$ in the Zagros Mountains by mid-century.

By end-century, the expected increase in temperature is more dramatic, generally exceeding $4{ }^{\circ} \mathrm{C}$ for RCP8.5, the more likely scenario [41]. The EU is most affected, signaling increases $>5^{\circ} \mathrm{C}$ during spring (MAM) and summer (JJA). Similarly, the Senegal River (SR) also projects an increase $>5^{\circ} \mathrm{C}$ during the winter (DJF).

Precipitation is more variable and exhibits seasonality. The Moroccan Highlands (MH) projects the greatest decreases in precipitation for both RCP4.5 (Table 4, Figure S3) and RCP8.5 (Table 5, Figure S4). During winter (DJF), a significant decrease is expected (up to $47 \%$ ) by end-century. Spring (MAM) also projects a definitive decrease in rainfall. Decreases to a lesser extent are expected in the Western Mashreq (WM) and Ethiopian Highlands (EH); the latter represents the headwaters of the Nile River basin.

Table 2. Mean ensemble change in temperature $\left({ }^{\circ} \mathrm{C}\right)$ compared to the reference period for selected subdomains, $\mathrm{RCP} 4.5$, based on three downscaled GCMs and one RCM.

\begin{tabular}{ccccccccccccc}
\hline \multirow{2}{*}{ Subdomain } & \multicolumn{3}{c}{ Reference Period (1986-2005) } & \multicolumn{3}{c}{ Mid-Century (2046-2065) } & \multicolumn{3}{c}{ End-Century (2081-2100) } \\
\cline { 2 - 11 } & DJF & MAM & JJA & SON & DJF & MAM & JJA & SON & DJF & MAM & JJA & SON \\
\hline MH & 9.6 & 16.4 & 26.9 & 18.7 & 2.0 & 1.5 & 0.6 & 1.4 & 1.5 & 2.0 & 1.9 & 2.1 \\
MD & 13.6 & 20.4 & 27.7 & 22.6 & 1.6 & 1.4 & 0.7 & 1.1 & 1.3 & 1.5 & 1.9 & 1.7 \\
SR & 25.5 & 31.2 & 27.4 & 26.9 & 1.8 & 1.0 & 1.9 & 1.8 & 2.4 & 1.8 & 2.3 & 1.9 \\
EU & -0.8 & 9.7 & 22.9 & 13.1 & 2.9 & 2.2 & 0.9 & 1.5 & 2.0 & 2.4 & 2.5 & 2.0 \\
WM & 8.8 & 17.0 & 26.3 & 19.8 & 2.1 & 1.5 & 0.6 & 1.3 & 1.5 & 1.6 & 1.8 & 1.9 \\
ZM & 4.2 & 15.7 & 27.7 & 17.4 & 3.0 & 2.0 & 0.8 & 1.6 & 2.3 & 2.1 & 2.3 & 2.1 \\
WA & 15.5 & 25.5 & 33.7 & 26.2 & 2.4 & 1.7 & 0.6 & 1.4 & 2.0 & 1.8 & 1.8 & 1.8 \\
LS & 20.9 & 30.0 & 31.3 & 27.8 & 2.2 & 1.6 & 1.7 & 1.9 & 2.4 & 2.4 & 2.4 & 2.3 \\
EH & 20.7 & 23.7 & 21.6 & 21.2 & 1.6 & 1.5 & 1.3 & 1.4 & 2.1 & 2.1 & 1.6 & 1.6 \\
HA & 24.5 & 27.5 & 27.5 & 26.3 & 1.0 & 1.3 & 1.0 & 1.0 & 1.3 & 2.0 & 1.3 & 1.3 \\
RV & 24.0 & 24.0 & 22.3 & 23.6 & 1.2 & 1.2 & 1.4 & 1.1 & 1.7 & 1.4 & 1.6 & 1.5 \\
\hline
\end{tabular}


Table 3. Mean ensemble change in temperature $\left({ }^{\circ} \mathrm{C}\right)$ compared to the reference period for selected subdomains, RCP8.5, based on three downscaled GCMs and one RCM.

\begin{tabular}{ccccccccccccc}
\hline \multirow{2}{*}{ Subdomain } & \multicolumn{3}{c}{ Reference Period (1986-2005) } & \multicolumn{3}{c}{ Mid-Century (2046-2065) } & \multicolumn{3}{c}{ End-Century (2081-2100) } \\
\cline { 2 - 11 } & DJF & MAM & JJA & SON & DJF & MAM & JJA & SON & DJF & MAM & JJA & SON \\
\hline MH & 9.6 & 16.4 & 26.9 & 18.7 & 2.8 & 2.7 & 1.2 & 2.1 & 3.4 & 4.4 & 4.2 & 4.4 \\
MD & 13.6 & 20.3 & 27.7 & 22.6 & 2.3 & 1.7 & 1.3 & 1.8 & 2.8 & 3.2 & 3.8 & 3.6 \\
SR & 25.5 & 31.2 & 27.4 & 26.9 & 2.8 & 1.7 & 2.4 & 2.4 & 5.1 & 3.8 & 4.4 & 4.0 \\
EU & -0.8 & 9.7 & 22.8 & 13.2 & 3.5 & 3.2 & 1.6 & 1.9 & 4.1 & 5.2 & 5.3 & 4.3 \\
WM & 8.8 & 16.9 & 26.3 & 19.9 & 2.6 & 2.0 & 1.0 & 1.7 & 3.2 & 3.5 & 3.6 & 4.0 \\
ZM & 4.2 & 15.6 & 27.7 & 17.5 & 3.7 & 2.6 & 1.6 & 2.3 & 4.6 & 4.6 & 4.8 & 4.5 \\
WA & 15.5 & 25.4 & 33.7 & 26.2 & 3.1 & 2.3 & 1.3 & 2.0 & 4.2 & 4.1 & 3.7 & 3.9 \\
LS & 20.9 & 30.0 & 31.3 & 27.9 & 3.1 & 2.1 & 2.3 & 2.5 & 4.9 & 4.6 & 4.6 & 4.6 \\
EH & 20.7 & 23.7 & 21.6 & 21.2 & 2.2 & 2.0 & 1.7 & 1.8 & 4.2 & 4.3 & 3.0 & 3.1 \\
HA & 24.5 & 27.5 & 27.5 & 26.3 & 1.4 & 1.9 & 1.4 & 1.5 & 2.6 & 4.0 & 2.5 & 2.7 \\
RV & 24.1 & 24.0 & 22.3 & 23.6 & 1.7 & 1.7 & 1.9 & 1.6 & 3.7 & 3.2 & 3.3 & 3.1 \\
\hline
\end{tabular}

Note: Refer to Figure 1 for the full names and locations of the subdomains.

Table 4. Mean ensemble change in precipitation ( $\mathrm{mm} / \mathrm{month})$ compared to the reference period for selected subdomains, RCP4.5, based on three downscaled GCMs and one RCM.

\begin{tabular}{ccccccccccccc}
\hline \multirow{2}{*}{ Subdomain } & \multicolumn{3}{c}{ Reference Period (1986-2005) } & \multicolumn{3}{c}{ Mid-Century (2046-2065) } & \multicolumn{3}{c}{ End-Century (2081-2100) } \\
\cline { 2 - 12 } & DJF & MAM & JJA & SON & DJF & MAM & JJA & SON & DJF & MAM & JJA & SON \\
\hline MH & 30.7 & 24.3 & 4.6 & 24.3 & -6.3 & -2.1 & 0.6 & -3.3 & -4.8 & -4.8 & 0.3 & -3.0 \\
MD & 18.4 & 4.3 & 1.0 & 6.3 & -0.7 & 0.6 & 0.0 & 0.5 & 1.9 & -0.4 & -0.1 & 0.1 \\
SR & 0.4 & 24.1 & 205.4 & 81.3 & -0.2 & 0.5 & 1.4 & 3.6 & -0.1 & 2.2 & -3.6 & 7.6 \\
EU & 63.3 & 64.0 & 11.3 & 40.8 & 5.0 & 4.1 & 0.3 & 1.0 & 6.8 & 2.8 & 1.3 & -3.6 \\
WM & 51.7 & 20.7 & 1.8 & 19.1 & 1.5 & 1.3 & -0.1 & -0.1 & 2.1 & -0.2 & 0.0 & -3.9 \\
ZM & 48.5 & 36.6 & 2.7 & 20.9 & -1.6 & 3.7 & 0.1 & 3.4 & 1.4 & 0.6 & 0.5 & 0.2 \\
WA & 10.7 & 16.1 & 2.8 & 7.3 & -1.4 & 0.3 & 0.6 & 2.2 & -0.3 & 0.2 & 0.6 & 0.9 \\
LS & 0.0 & 3.1 & 47.2 & 7.9 & 0.0 & 0.1 & -1.8 & 0.6 & 0.0 & -0.4 & -6.4 & 1.7 \\
EH & 8.2 & 57.3 & 202.0 & 71.0 & -1.7 & -6.1 & -8.1 & -0.4 & 0.3 & -5.5 & -8.0 & 0.4 \\
HA & 4.6 & 30.9 & 8.5 & 29.7 & 1.0 & 0.1 & -0.1 & 8.1 & 2.3 & 4.2 & 0.0 & 8.5 \\
RV & 48.9 & 98.5 & 39.3 & 80.8 & 6.1 & 4.3 & -1.9 & 6.7 & 13.6 & 12.4 & 0.3 & 5.7 \\
\hline
\end{tabular}

Note: Refer to Figure 1 for the full names and locations of the subdomains.

Table 5. Mean ensemble change in precipitation ( $\mathrm{mm} / \mathrm{month})$ compared to the reference period for selected subdomains, RCP8.5, based on three downscaled GCMs and one RCM.

\begin{tabular}{ccccccccccccc}
\hline \multirow{2}{*}{ Subdomain } & \multicolumn{3}{c}{ Reference Period (1986-2005) } & \multicolumn{3}{c}{ Mid-Century (2046-2065) } & \multicolumn{3}{c}{ End-Century (2081-2100) } \\
\cline { 2 - 12 } & DJF & MAM & JJA & SON & DJF & MAM & JJA & SON & DJF & MAM & JJA & SON \\
\hline MH & 29.9 & 24.1 & 4.6 & 25.0 & -7.8 & -4.5 & 0.5 & -3.8 & -14.1 & -10.0 & 0.9 & -5.3 \\
MD & 18.9 & 4.2 & 1.0 & 7.1 & -2.5 & 0.1 & -0.1 & -0.8 & -3.1 & -0.9 & -0.3 & -1.2 \\
SR & 0.3 & 23.8 & 204.8 & 81.6 & 0.0 & 1.8 & 5.1 & 4.7 & -0.1 & 1.7 & 13.7 & 15.0 \\
EU & 64.9 & 62.8 & 11.4 & 40.6 & -0.7 & 5.6 & -0.1 & -2.8 & -2.5 & 2.7 & 0.6 & -0.4 \\
WM & 52.2 & 20.5 & 1.7 & 19.0 & -3.2 & 0.3 & -0.4 & -1.8 & -4.5 & -1.9 & -0.3 & -3.8 \\
ZM & 48.4 & 37.0 & 2.8 & 20.6 & 0.3 & -0.3 & 0.4 & -1.0 & -0.1 & -3.8 & 0.2 & 1.8 \\
WA & 10.4 & 16.3 & 2.8 & 7.1 & -1.8 & 0.3 & 0.9 & 1.1 & -1.7 & -2.6 & 1.6 & 2.6 \\
LS & 0.0 & 3.1 & 46.5 & 7.6 & 0.0 & 0.3 & -0.7 & 1.4 & 0.0 & 0.5 & 5.1 & 3.9 \\
EH & 7.9 & 57.5 & 201.2 & 70.0 & -0.6 & -3.5 & -1.0 & 1.0 & -1.4 & -7.4 & -0.5 & 4.7 \\
HA & 4.4 & 31.0 & 8.2 & 28.7 & 2.9 & 1.4 & -0.5 & 8.1 & 3.4 & 5.4 & 0.9 & 13.6 \\
RV & 48.1 & 98.6 & 39.5 & 79.7 & 9.8 & 4.8 & -1.9 & 8.2 & 16.2 & 13.3 & -2.1 & 14.9 \\
\hline
\end{tabular}

Note: Refer to Figure 1 for the full names and locations of the subdomains.

Conversely, other areas in the Arab domain project an increase in seasonal precipitation. By end-century, summer (JJA) trends disagree in the Senegal River (SR), but project a notable increase (up to 18\%) during autumn (SON). The Rift Valley (RV) also signals 
increasing precipitation through most of the year; the greatest increase is $34 \%$ during winter (DJF).

\subsection{Calculation of SPI}

The Standardized Precipitation Index (SPI) is a well-recognized drought indicator developed by McKee et al. [42] and recommended by the World Meteorological Organization. Based solely on precipitation, the index is simple to calculate and can be applied at multiple temporal scales. Calculations are based on long-term precipitation records, which are fitted to a probability distribution, and then transformed into a normal distribution such that the mean SPI for a given location is zero. Positive values indicate wetter conditions and negative values signal drier conditions. A drought event occurs when the SPI is continuously negative and reaches an intensity of $\leq-1.0$. The drought concludes once the SPI no longer is $\leq 0$ and values are positive. The drought intensity is determined by the absolute value of the summed SPI during the drought duration [42].

In this context, the 3-month SPI (SPI-3) was calculated for each of the four climatological seasons: winter from December to February (DJF), spring from March to May (MAM), summer from June to August (JJA), and autumn from September to November (SON). This indicator was selected because of its ability to identify agricultural drought as demonstrated by its strong correlation with vegetation response [43]. For SPI-3, a drought event commences once the SPI reaches -1.0 or less for two consecutive months [44]. Droughts are considered severe if during an event, the index reaches a value of $\leq-1.5$ at least once and extreme if it is $\leq-2.0$ [42].

Monthly RCM outputs from 1970 to 2100 were used to fit the underlying SPI distribution, similar to the methodology described by Spinoni et al. [45]. This approach minimize bias; if periods were calculated separately, historical conditions established as the norm may be regarded as an outlier in the future, thus rendering future drought conditions as unrealistic [45]. Each of the RCM outputs were converted to raster data. SPI calculations were calculated separately for each RCM model in ArcMap (version 10.6) using the SPI calculator developed by Jo [46], which uses an algorithm based on SPI calculations.

The resultant SPI-3 values were processed and presented based on the mean value based on all models for each scenario. Drought events were determined for each $0.44^{\circ}$ pixel using the 'run theory' [47] by identifying the commencement of drought events, the severity, and the duration. Drought frequency (DF) is defined by the average number of events over a 10-year period for each season, evaluated for three different time periods: the reference period (1986-2005), mid-century (2046-2065), and end-century (2081-2100). The drought severity (DS) refers to the average severity for each of the same time periods.

\section{Results and Discussion}

Historical and projected drought was calculated based on the 3-month SPI using precipitation obtained from bias-corrected regional climate modelling outputs. The mean change in the number of events based on RCP4.5 (Figure 2) and RCP8.5 (Figure 3) reveal projected seasonal drought variability. It is noted that although the historical RCM outputs are independent of the future scenarios, bias-corrected historical models will have some slight differences due to the overlapping control period. Bias correction is conducted for the entire data period; thus, model output will marginally vary whether the historical data was coupled with RCP4.5 or RCP8.5. These minor disparities are transferred to the SPI calculations but the difference in the result are minimal. The reported change in drought frequency at mid- and end-century correspond to the appropriate reference period, whether based on RCP4.5 or RCP8.5. 

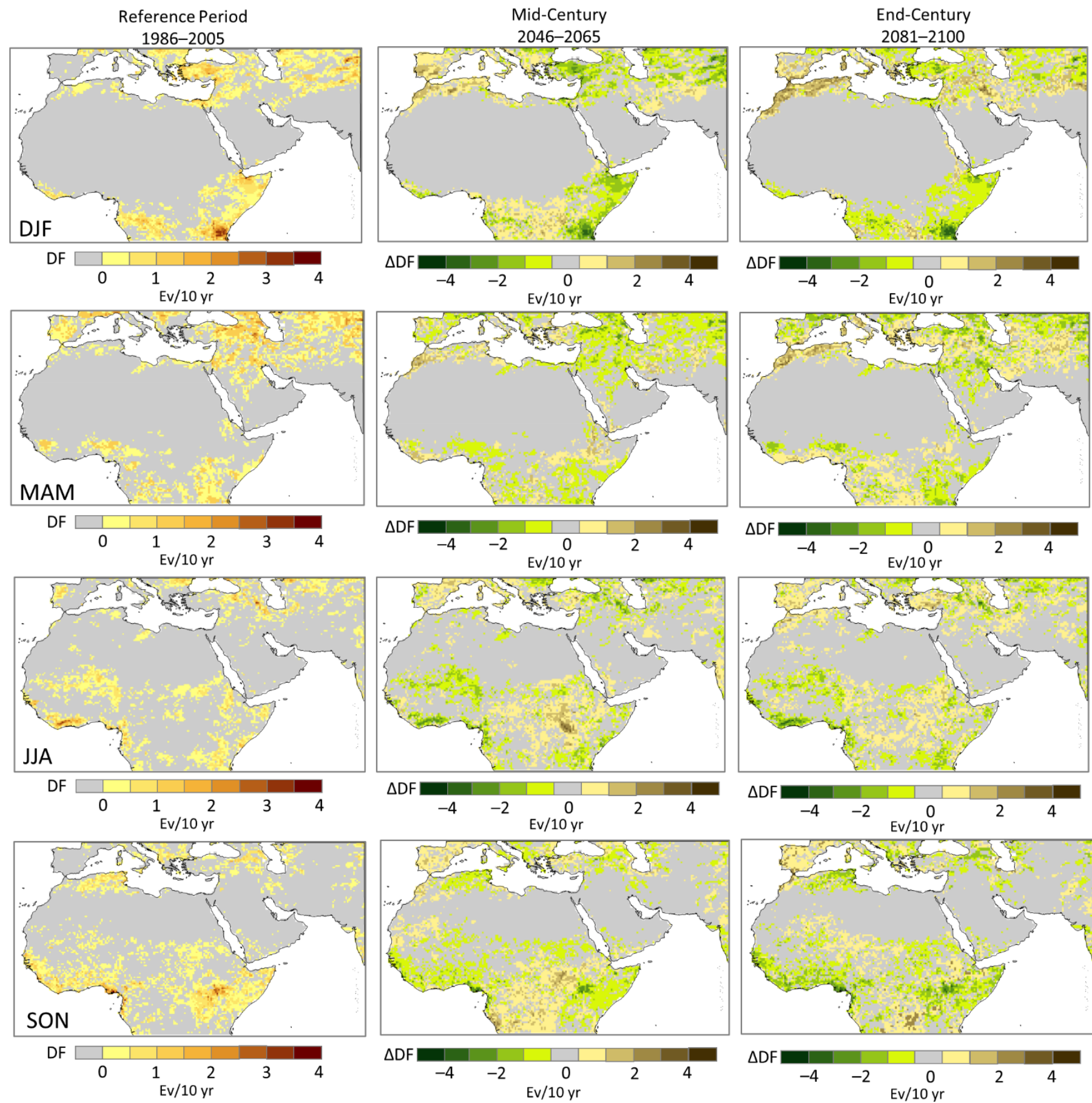

Figure 2. Mean change in drought frequency (DF; events per decade) at mid-century (middle) and end-century (right) compared to the reference period (left) based on RCP4.5 for winter (DJF), spring (MAM), summer (JJA), and autumn (SON), based on three downscaled GCMs and one RCM and SPI-3. 

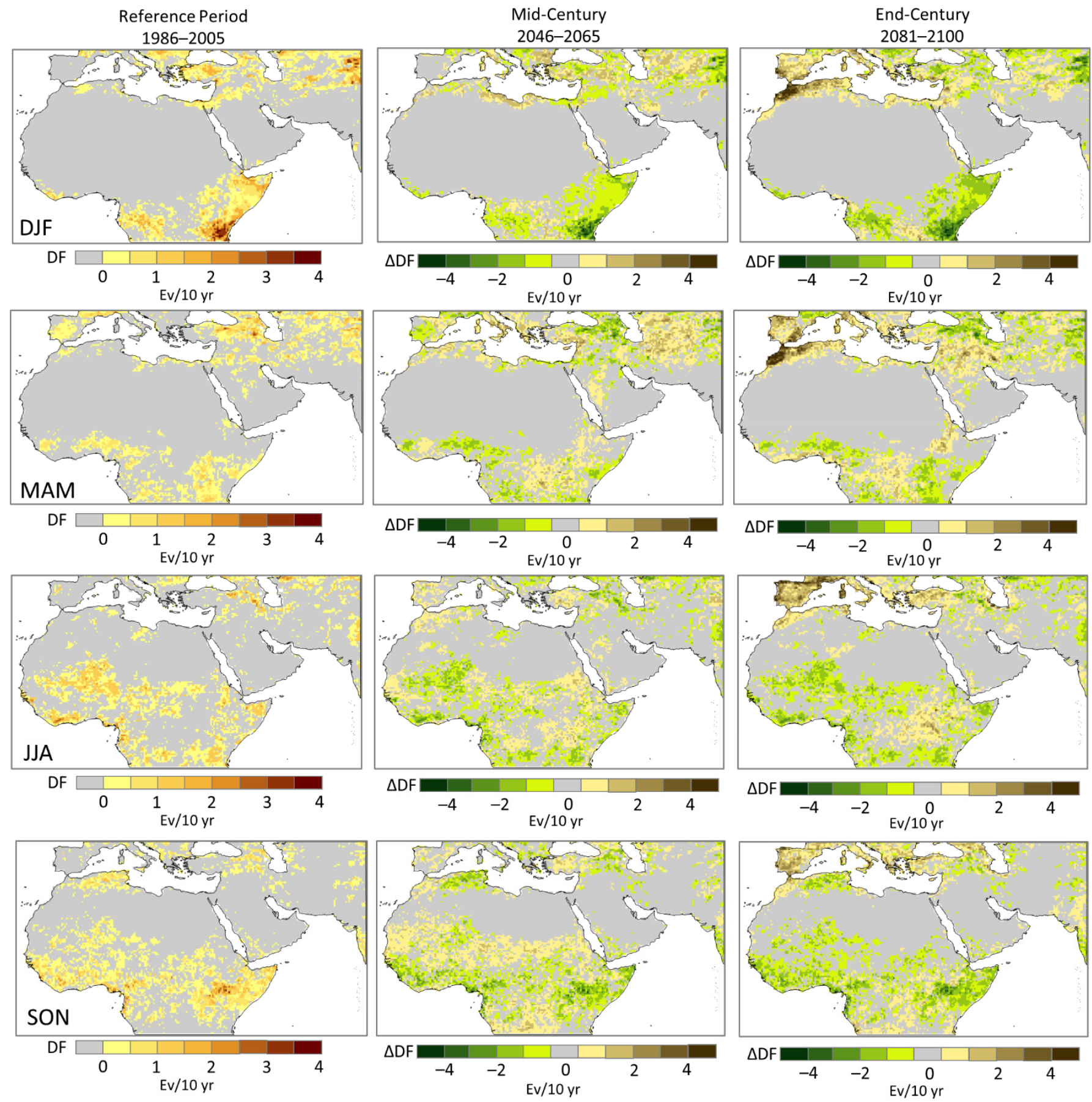

Figure 3. Mean change in drought frequency (DF; events per decade) at mid-century (middle) and end-century (right) compared to the reference period (left) based on RCP8.5 for winter (DJF), spring (MAM), summer (JJA), and autumn (SON), based on three downscaled GCMs and one RCM and SPI-3.

SPI-3 was indeterminate during the winter (DJF) season in the Lower Sahara Desert (LS). During this period, precipitation is zero, both for the reference period and future periods for both scenarios (Tables 4 and 5). SPI is problematic in hyperarid regions because the index is dependent on the normalization of precipitation data. Null precipitation values are unable to be fitted to a gamma distribution and thus SPI is incalculable [48].

During the recent reference period, the Rift Valley (RV) revealed high recurrence of drought during the winter months (DJF). This was attributed to westerly low-level moisture flux divergence and subsidence linked to an eastward shift of atmospheric circulation [49]. To a lesser extent, winter repeated events are apparent in the Horn of Africa (HA), 
consistent with previous studies $[23,50]$. However, precipitation is projected to generally increase through end-century for both scenarios (Tables 4 and 5) owing to western Indian Ocean warming, resulting in less drought frequency (DF). Nevertheless, strong interannual variability is expected to persist due to El Niño-Southern Oscillation and dipole phenomena [51].

Conversely, the Moroccan Highlands and adjacent Mediterranean coast indicated little drought recurrence during the reference period for all seasons. Seasonal drought is expected to increase significantly, particularly during the winter (DJF) and spring (MAM) months by end-century. This expected trend is caused by changes in the North Atlantic Oscillation, cyclonic activity shifting northward, and Azores High transference [52].

To a lesser extent, drought frequency is expected to increase during the autumn (SON) in Morocco. This period coincides with the seedling stage of rainfed crops. Increase DF during the winter (DJF) and spring (MAM) growth periods is expected to induce adverse impacts upon soil moisture and plant transpiration, thus reducing the length of the growth period. As a result, rainfed wheat (durum) yield is expected to decrease $13 \%$ by mid-century near Rabat, Morocco [53].

Projected DF trends over the greater Mashreq (including WM, EU, and ZM) are in disagreement, particularly during the spring (MAM). By mid-century, the area will exhibit a decrease in events, particularly for RCP4.5 (Figure 2), but an increase by end-century for RCP8.5 (Figure 3). These projected changes will have an unclear impact upon sand and dust storm (SDS). SDS activity prevails during April-June in the region, due to south and south-easterly winds known as "sharqi" [12]. Although SPI demonstrates a weak positive correlation with SDS [10], increasing DF may give rise to increased dust particles that can be carried by the turbulent sharqi wind systems [11]. Dust storm frequency also occurs during the SON period, due to north-westerly winds called "shamal" [12]; however, changes in DF during this period are nearly nil.

Although increasing DF is generally negligible during the autumn (SON), isolated areas signal an increase in DF. Drought has been linked to recurrent forest fires in Lebanon, including several simultaneous fires that occurred in October 2019 [54].

Drought frequency is interlinked with drought severity (DS). The severity of an event is determined by the absolute value of the sum of all SPI values during an event. Here, DS is defined by average severity, not the total severity, for both RCP4.5 (Figure 4) and RCP8.5 (Figure 5). Although DF and DS exhibit a strong correlation ( 0.8), certain regions may expect a modest increase in DF, but a definitive increase in DS. For example, the Ethiopian Highlands (EH) projects a 4\% decrease in rainfall during summer (JJA, Table 4); corresponding DF will increase slightly coupled with a $73 \%$ increase in severity by midcentury. In the Moroccan Highlands (MH) and adjacent Mediterranean coast, end-century drought increases during winter (DJF) do correspond to increasing DS. However, in this same area, increasing DS is approximately the same magnitude during summer (JJA), but event frequency only changes slightly. 

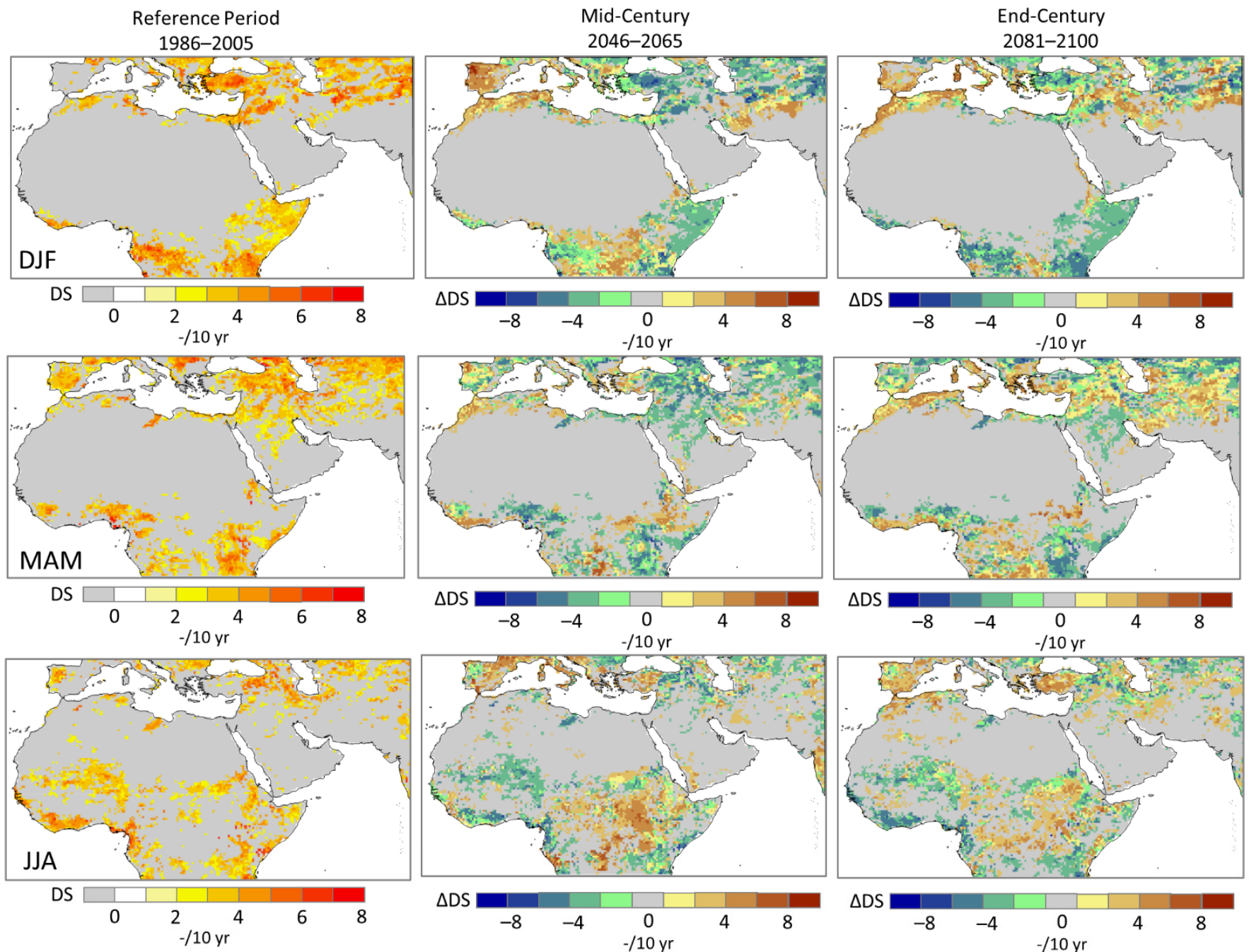

$\triangle \mathrm{DS}$
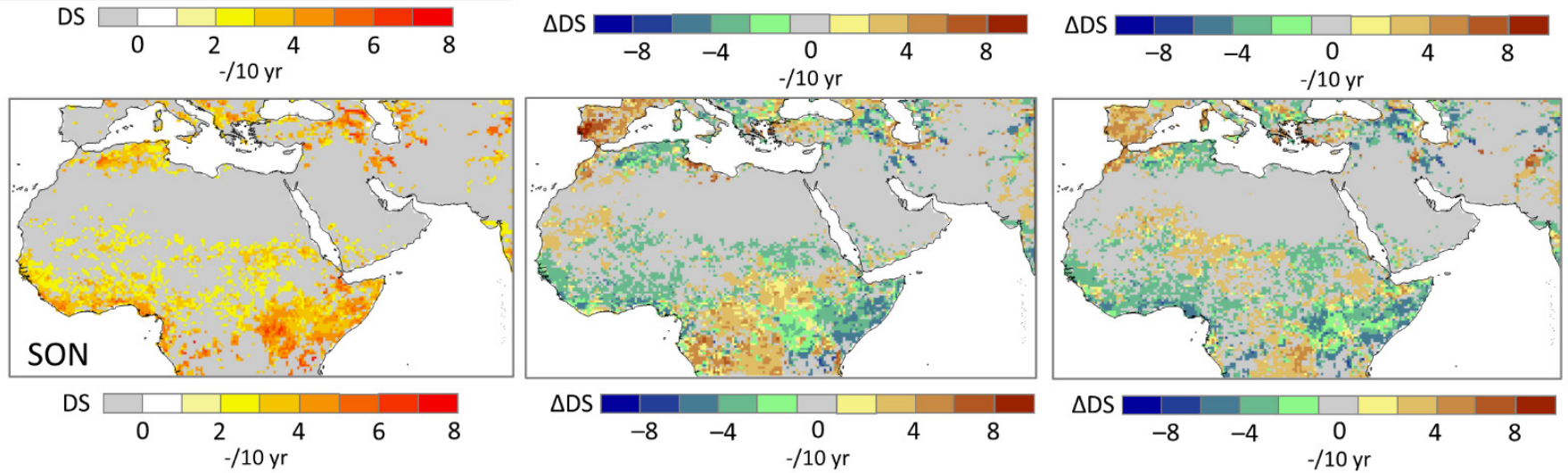

Figure 4. Mean change in drought severity (DS; per decade) at mid-century (middle) and end-century (right) compared to the reference period (left) based on RCP4.5 for winter (DJF), spring (MAM), summer (JJA), and autumn (SON), based on three downscaled GCMs and one RCM and SPI-3. 

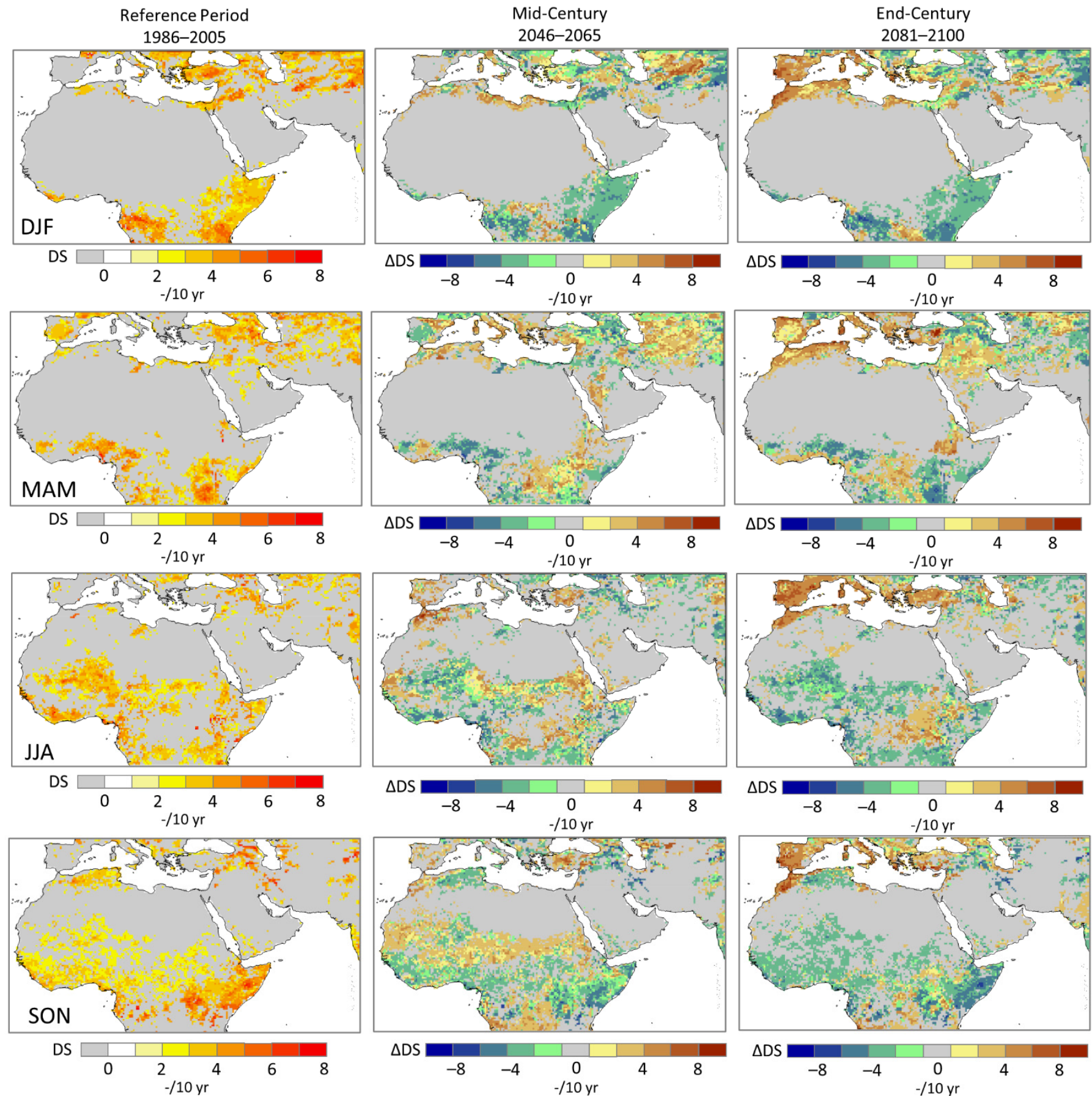

Figure 5. Mean change in drought severity (DS; per decade) at mid-century (middle) and end-century (right) compared to the reference period (left) based on RCP8.5 for winter (DJF), spring (MAM), summer (JJA), and autumn (SON), based on three downscaled GCMs and one RCM and SPI-3.

\section{Concluding Remarks}

Across the Arab region, projected changes in seasonal drought exhibit spatial and temporal variability. The Moroccan Highlands and adjacent coast are expecting significantly increasing drought frequency and severity, particularly during the winter (DJF) and spring (MAM) months by end-century. To a lesser extent, seasonal drought is also expected to increase in the greater Mashreq region. This increasing drought provokes grave concerns in the water scarce Arab region. Seasonal drought has been linked to decreasing crop yield in Morocco, SDS in Iraq, and forest fires in Lebanon. These disasters are expected to recur 
due to climate change. Although drought cannot be prevented, action can be taken to mitigate impacts.

On the other hand, future seasonal drought is expected to recur less often in subSaharan Africa, including the Rift Valley due to projected increasing precipitation. However, such conditions can bring about other challenges such as flood. In addition, strong yearto-year rainfall fluctuations are expected to continue, stemming from El Niño-Southern Oscillation and Indian Ocean dipole phenomena.

The Arab region accounts for approximately $5 \%$ of global greenhouse gas emissions, but demand growth in Gulf Cooperation Council (GCC) countries is of concern. On a per capita basis, GCC economies are among the highest carbon dioxide $\left(\mathrm{CO}_{2}\right)$ emitters, surpassing some industrialized countries [55]. However, most population groups in the region that are most affected by climate change have negligible impact on emissions. Thus, adaptation measures to mitigate impacts, including drought, are necessary.

Geospatial assessments help identify areas most vulnerable to drought to target adaptation measures. Successful agricultural measures in the region include shifting the crop calendar [53], cultivating drought-tolerant crops [56], and rainwater harvesting [57]. Non-conventional water resources, including fog and dew, have been proposed to mitigate drought in forests [58], reducing fire risk. Any proposed adaptation measures should consider rapid urbanization, migration, and land use change, often overlooked [59].

This study was the first to evaluate future drought frequency and severity across the Arab region. Future research includes meteorological and hydrological drought to assess impacts upon reservoirs and groundwater. Moreover, this study solely focused on SPI, which only considers precipitation, eliminating temperature. Thus, other drought indices such as the Standardised Precipitation-Evapotranspiration Index (SPEI) [60] may offer an improved assessment. RCM outputs at a $10 \mathrm{~km}$ spatial scale for the greater Mashreq domain are forthcoming soon from RICCAR, which will enable more detailed analysis.

Supplementary Materials: The following are available online at https://www.mdpi.com/article/ 10.3390/atmos12070856/s1, Figure S1: Mean change in temperature $\left({ }^{\circ} \mathrm{C}\right.$ ) at mid-century (middle) and end-century (right) compared to the reference period (left) based on RCP4.5 for winter (DJF), spring (MAM), summer (JJA), and autumn $(\mathrm{SON})$, Figure S2: Mean change in temperature $\left({ }^{\circ} \mathrm{C}\right)$ at mid-century (middle) and end-century (right) compared to the reference period (left) based on RCP8.5 for winter (DJF), spring (MAM), summer (JJA), and autumn (SON), Figure S3: Mean change in precipitation (mm/month) at mid-century (middle) and end-century (right) compared to the reference period (left) based on RCP4.5 for winter (DJF), spring (MAM), summer (JJA), and autumn $(\mathrm{SON})$, Figure S4: Mean change in precipitation $(\mathrm{mm} / \mathrm{month}$ ) at mid-century (middle) and endcentury (right) compared to the reference period (left) based on RCP8.5 for winter (DJF), spring (MAM), summer (JJA), and autumn (SON).

Funding: This research received no external funding.

Institutional Review Board Statement: Not applicable.

Informed Consent Statement: Not applicable.

Data Availability Statement: Bias-corrected regional climate modelling outputs for the CORDEXMENA domain are available from the RICCAR Regional Knowledge Hub data portal (www.riccar.org, accessed on 22 March 2021) or by email request sent to escwa-h2o@un.org.

Acknowledgments: The author would like to acknowledge the Swedish International Development Cooperation Agency (Sida) and their contributed support of RICCAR. RICCAR is a joint initiative of the United Nations and the League of Arab States launched in 2010. It was implemented through a collaborative partnership involving 11 regional and specialized organizations and coordinated by the United Nations Economic and Social Commission for Western Asia (ESCWA). The author would also like to thank the Editor and the two anonymous reviewers for their comments.

Conflicts of Interest: The author declares no conflict of interest. 


\section{References}

1. Hameed, M.; Moradkhani, H.; Ahmadalipour, A.; Moftakhari, H.; Abbaszadeh, P.; Alipour, A. A Review of the 21st Century Challenges in the Food-Energy-Water Security in the Middle East. Water 2019, 11, 682. [CrossRef]

2. Hameed, M.; Ahmadalipour, A.; Moradkhani, H. Drought and food security in the middle east: An analytical framework. Agric. For. Meteorol. 2020, 281, 107816. [CrossRef]

3. Cheeseman, J. Food security in the face of salinity, drought, climate change, and population growth. In Halophytes for Food Security in Dry Lands; Elsevier: Amsterdam, The Netherlands, 2016; pp. 111-123.

4. Teklu, T.; Von Braun, J.; Zaki, E. Drought and famine relationships in Sudan: Policy implications". International Food Policy Research Institute. Food Nutr. Bull. 1992, 14, 1-3. [CrossRef]

5. Lotsch, A.; Friedl, M.A.; Anderson, B.T.; Tucker, C.J. Response of terrestrial ecosystems to recent Northern Hemispheric drought. Geophys. Res. Lett. 2005, 32, 32. [CrossRef]

6. Olagunju, T.E. Drought, desertification and the Nigerian environment: A review. J. Ecol. Nat. Environ. 2015, 7, 196-209. [CrossRef]

7. El Kharraz, J.; El-Sadek, A.; Ghaffour, N.; Mino, E. Water scarcity and drought in WANA countries. Procedia Eng. 2012, 33, 14-29. [CrossRef]

8. Modarres, R.; Sarhadi, A.; Burn, D.H. Changes of extreme drought and flood events in Iran. Glob. Planet. Chang. 2016, 144, 67-81. [CrossRef]

9. Parente, J.; Amraoui, M.; Menezes, I.; Pereira, M.G. Drought in Portugal: Current regime, comparison of indices and impacts on extreme wildfires. Sci. Total Environ. 2019, 685, 150-173. [CrossRef]

10. Yahya, B.M.; Seker, D.Z. The Impact of Dust and Sandstorms in Increasing Drought Areas in Nineveh Province, North-western Iraq. J. Asian Afr. Stud. 2019, 54, 346-359. [CrossRef]

11. Notaro, M.; Yu, Y.; Kalashnikova, O.V. Regime shift in Arabian dust activity, triggered by persistent Fertile Crescent drought. J. Geophys. Res. Atmos. 2015, 120, 10229-10249. [CrossRef]

12. Al Ameri, I.D.; Briant, R.M.; Engels, S. Drought severity and increased dust storm frequency in the Middle East: A case study from the Tigris-Euphrates alluvial plain, central Iraq. Weather 2019, 74, 416-426. [CrossRef]

13. Kaniewski, D.; Van Campo, E.; Weiss, H. Drought is a recurring challenge in the Middle East. Proc. Natl. Acad. Sci. USA 2012, 109, 3862-3867. [CrossRef]

14. Feitelson, E.; Tubi, A. A main driver or an intermediate variable? Climate change, water and security in the Middle East. Glob. Environ. Chang. 2017, 44, 39-48. [CrossRef]

15. Ide, T. Climate war in the Middle East? Drought, the Syrian civil war and the state of climate-conflict research. Curr. Clim. Chang. Rep. 2018, 4, 347-354. [CrossRef]

16. Mathbout, S.; Lopez-Bustins, J.A.; Martin-Vide, J.; Bech, J.; Rodrigo, F.S. Spatial and temporal analysis of drought variability at several time scales in Syria during 1961-2012. Atmos. Res. 2018, 200, 153-168. [CrossRef]

17. Barlow, M.; Zaitchik, B.; Paz, S.; Black, E.; Evans, J.; Hoell, A. Review of Drought in the Middle East and Southwest Asia. J. Clim. 2016, 29, 8547-8574. [CrossRef]

18. Riehl, S.; Pustovoytov, K.E.; Weippert, H.; Klett, S.; Hole, F. Drought stress variability in ancient Near Eastern agricultural systems evidenced by $813 C$ in barley grain. Proc. Natl. Acad. Sci. USA 2014, 111, 12348-12353. [CrossRef] [PubMed]

19. Bruins, H.J. Ancient desert agriculture in the Negev and climate-zone boundary changes during average, wet and drought years. J. Arid Environ. 2012, 86, 28-42. [CrossRef]

20. Donat, M.G.; Peterson, T.C.; Brunet, M.; King, A.D.; Almazroui, M.; Kolli, R.K.; Boucherf, D.; Al-Mulla, A.Y.; Nour, A.Y.; Aly, A.A.; et al. Changes in extreme temperature and precipitation in the Arab region: Long-term trends and variability related to ENSO and NAO. Int. J. Climatol. 2013, 34, 581. [CrossRef]

21. United Nations Economic and Social Commission for Western Asia (ESCWA). Arab Climate Change Assessment Report-Main Report; E/ESCWA/SDPD/2017/RICCAR/Report; United Nations Economic and Social Commission for Western Asia (ESCWA): Beirut, Lebanon, 2017.

22. Aladaileh, H.; Al Qinna, M.; Karoly, B.; Al-Karablieh, E.; Rakonczai, J. An Investigation into the Spatial and Temporal Variability of the Meteorological Drought in Jordan. Climate 2019, 7, 82. [CrossRef]

23. Spinoni, J.; Barbosa, P.; De Jager, A.; McCormick, N.; Naumann, G.; Vogt, J.V.; Magni, D.; Masante, D.; Mazzeschi, M. A new global database of meteorological drought events from 1951 to 2016. J. Hydrol. Reg. Stud. 2019, 22, 100593. [CrossRef]

24. Zittis, G.; Zittis, G. Observed rainfall trends and precipitation uncertainty in the vicinity of the Mediterranean, Middle East and North Africa. Appl. Clim. 2018, 134, 1207-1230. [CrossRef]

25. Al Bitar, A.; Najem, S.; Jarlan, L.; Zribi, M.; Faour, G. Precipitation and Soil Moisture Datasets Show Severe Droughts in the MENA Region; Research Square Company: Durham, NC, USA, 2021.

26. Arab Center for the Studies of Arid Zones and Dry Lands (ACSAD). Climate Change Trends in the Arab Region and Their Impact on Water Resources (in Arabic); RICCAR Technical Report, E/ESCWA/SDPD/017/RICCAR/TechnicalReport.4/rev.1; Arab Center for the Studies of Arid Zones and Dry Lands (ACSAD): Beirut, Lebanon, 2017.

27. Almazroui, M. Assessment of meteorological droughts over Saudi Arabia using surface rainfall observations during the period 1978-2017. Arab. J. Geosci. 2019, 12, 1-16. [CrossRef] 
28. Hamdan, A.N.A.; Nasir, H.N.; Naseh, A.; Hamdan, A. Article ID: IJCIET_10_12_016 Cite this Article: Hamza Neamah Nasir and Dr. Ahmed Naseh Ahmed Hamdan, Drought Hazard Assessment in Iraq using SPI and GIS Systems. Int. J. Civ. Eng. Technol. (IJCIET) 2019, 10, 161.

29. Ouatiki, H.; Boudhar, A.; Ouhinou, A.; Arioua, A.; Hssaisoune, M.; Bouamri, H.; Benabdelouahab, T. Trend analysis of rainfall and drought over the Oum Er-Rbia River Basin in Morocco during 1970-2010. Arab. J. Geosci. 2019, 12, 1. [CrossRef]

30. Yacoub, E.; Tayfur, G. Spatial and temporal of variation of meteorological drought and precipitation trend analysis over whole Mauritania. J. Afr. Earth Sci. 2020, 163, 103761. [CrossRef]

31. Yang, W.; Andréasson, J.; Phil Graham, L.; Olsson, J.; Rosberg, J.; Wetterhall, F. Distribution-based scaling to improve usability of regional climate model projections for hydrological climate change impacts studies. Hydrol. Res. 2010, 41, 211-229. [CrossRef]

32. Weedon, G.P.; Balsamo, G.; Bellouin, N.; Gomes, S.; Best, M.J.; Viterbo, P. The WFDEI meteorological forcing data set: WATCH Forcing Data methodology applied to ERA-Interim reanalysis data. Water Resour. Res. 2014, 50, 7505-7514. [CrossRef]

33. Bosshard, T.; Yang, W.; Sjökvist, E.; Arheimer, B.; Graham, L. Bias-Correction of CORDEX-MENA Projections Using the Distribution Based Scaling Method, EGU General Assembly Conference Abstracts; EGU General Assembly: Vienna, Austria, $2014 ;$ p. 12989.

34. Wörner, V.; Kreye, P.; Meon, G. Effects of bias-correcting climate model data on the projection of future changes in high flows. Hydrology 2019, 6, 46. [CrossRef]

35. Mendez, M.; Maathuis, B.; Hein-Griggs, D.; Alvarado-Gamboa, L. Performance evaluation of bias correction methods for climate change monthly precipitation projections over Costa Rica. Water 2020, 12, 482. [CrossRef]

36. Johnson, F.; Sharma, A. What are the impacts of bias correction on future drought projections? J. Hydrol. 2015, 525, 472-485. [CrossRef]

37. Voldoire, A.; Sanchez-Gomez, E.; y Mélia, D.S.; Decharme, B.; Cassou, C.; Sénési, S.; Valcke, S.; Beau, I.; Alias, A.; Chevallier, M. The CNRM-CM5. 1 global climate model: Description and basic evaluation. Clim. Dyn. 2013, 40, 2091-2121. [CrossRef]

38. Koenigk, T.; Brodeau, L.; Graversen, R.G.; Karlsson, J.; Svensson, G.; Tjernström, M.; Willén, U.; Wyser, K. Arctic climate change in 21st century CMIP5 simulations with EC-Earth. Clim. Dyn. 2013, 40, 2719-2743. [CrossRef]

39. Dunne, J.P.; John, J.G.; Adcroft, A.J.; Griffies, S.M.; Hallberg, R.W.; Shevliakova, E.; Stouffer, R.J.; Cooke, W.; Dunne, K.A.; Harrison, M.J. GFDL's ESM2 global coupled climate-carbon earth system models. Part I: Physical formulation and baseline simulation characteristics. J. Clim. 2012, 25, 6646-6665. [CrossRef]

40. Samuelsson, P.; Gollvik, S.; Kupiainen, M.; Kourzeneva, E.; van de Berg, W.J. The Surface Processes of the Rossby Centre Regional Atmospheric Climate Model (RCA4); SMHI: Norrkoping, Sweden, 2015.

41. Schwalm, C.R.; Glendon, S.; Duffy, P.B. RCP8. 5 tracks cumulative $\mathrm{CO}_{2}$ emissions. Proc. Natl. Acad. Sci. USA 2020, 117, 19656-19657. [CrossRef]

42. McKee, T.B.; Doesken, N.J.; Kleist, J. The relationship of drought frequency and duration of time scales. In Eighth Conference on Applied Climatology; American Meteorological Society: Boston, MA, USA, 1993; pp. 179-186.

43. Sepulcre-Canto, G.; Horion, S.; Singleton, A.; Carrao, H.; Vogt, J. Development of a Combined Drought Indicator to detect agricultural drought in Europe. Nat. Hazards Earth Syst. Sci. 2012, 12, 3519-3531. [CrossRef]

44. Spinoni, J.; Naumann, G.; Vogt, J.V. Pan-European seasonal trends and recent changes of drought frequency and severity. Glob. Planet. Chang. 2017, 148, 113-130. [CrossRef]

45. Spinoni, J.; Barbosa, P.; Bucchignani, E.; Cassano, J.; Cavazos, T.; Christensen, J.H.; Christensen, O.B.; Coppola, E.; Evans, J.; Geyer, B.; et al. Future Global Meteorological Drought Hot Spots: A Study Based on CORDEX Data. J. Clim. 2020, 33, 3635-3661. [CrossRef]

46. Jo, H.W. Calculate Standardized Precipitation Index (SPI) in ArcGIS Version 3.0 (Computer Model). 2020. Available online: https:/ / github.com/Hyun-Woo-Jo/CalculateSPI/releases (accessed on 22 March 2021).

47. Yevjevich, V. An Objective Approach to Definitions and Investigations of Continental Hydrologic Droughts; Hydrol. Papers 23; Colorado State University Publication, Colorado State University: Fort Collins, CO, USA, 1967.

48. Alsumaiei, A.A.; Alrashidi, M.S. Hydrometeorological drought forecasting in hyper-arid climates using nonlinear autoregressive neural networks. Water 2020, 12, 2611. [CrossRef]

49. Kijazi, A.L.; Reason, C. Analysis of the 1998 to 2005 drought over the northeastern highlands of Tanzania. Clim. Res. 2009, 38, 209-223. [CrossRef]

50. Haile, G.G.; Tang, Q.; Leng, G.; Jia, G.; Wang, J.; Cai, D.; Sun, S.; Baniya, B.; Zhang, Q. Long-term spatiotemporal variation of drought patterns over the Greater Horn of Africa. Sci. Total Environ. 2020, 704, 135299. [CrossRef]

51. Liebmann, B.; Hoerling, M.P.; Funk, C.; Bladé, I.; Dole, R.M.; Allured, D.; Quan, X.; Pegion, P.; Eischeid, J.K. Understanding recent eastern Horn of Africa rainfall variability and change. J. Clim. 2014, 27, 8630-8645. [CrossRef]

52. Knippertz, P.; Christoph, M.; Speth, P. Long-term precipitation variability in Morocco and the link to the large-scale circulation in recent and future climates. Meteorol. Atmos. Phys. 2003, 83, 67-88. [CrossRef]

53. United Nations Economic and Social Commission for Western Asia (ESCWA); Arab Center for the Studies of Arid Zones and Dry Lands (ACSAD); Food and Agriculture Organization of the United Nations (FAO). Assessing the Impacts of Changing Water Availability on Agricultural Crops: Morocco Case Study (in Arabic); 6.CP/2019/SDPD/ESCWA/E; United Nations Digital Library: Beirut, Lebanon, 2019.

54. Kallab, A. Analyzing Lebanon's Vulnerability Using the PAR Model Case Study: The October 2019 Forest Fires; ResearchGate: Berlin, Germany, 2020. 
55. United Nations Economic and Social Commission for Western Asia (ESCWA). Energy Vulnerability in the Arab Region; E/ESCWA/SDPD/2019/1; United Nations Economic and Social Commission for Western Asia (ESCWA): Beirut, Lebanon, 2019.

56. Sadok, W.; Schoppach, R.; Ghanem, M.E.; Zucca, C.; Sinclair, T.R. Wheat drought-tolerance to enhance food security in Tunisia, birthplace of the Arab Spring. Eur. J. Agron. 2019, 107, 1-9. [CrossRef]

57. Amin, M.T.; Alazba, A.A.; ElNesr, M.N. Adaptation of climate variability/extreme in arid environment of the Arabian peninsula by rainwater harvesting and management. Int. J. Environ. Sci. Technol. 2013, 10, 27-36. [CrossRef]

58. Tomaszkiewicz, M.; Abou Najm, M.; Zurayk, R.; El-Fadel, M. Dew as an adaptation measure to meet water demand in agriculture and reforestation. Agric. Meteorol. 2017, 232, 411-421. [CrossRef]

59. Lele, S.; Srinivasan, V.; Thomas, B.K.; Jamwal, P. Adapting to climate change in rapidly urbanizing river basins: Insights from a multiple-concerns, multiple-stressors, and multi-level approach. Water Int. 2018, 43, 281-304. [CrossRef]

60. Beguería, S.; Vicente-Serrano, S.M.; Reig, F.; Latorre, B. Standardized precipitation evapotranspiration index (SPEI) revisited: Parameter fitting, evapotranspiration models, tools, datasets and drought monitoring. Int. J. Climatol. 2014, 34, $3001-3023$. [CrossRef] 